\title{
Education, queer theology, and spiritual development: disrupting heteronormativity for inclusion in Jewish, Muslim and Christian faith schools
}

\section{Seán Henry}

To cite this article: Seán Henry (2018) Education, queer theology, and spiritual development: disrupting heteronormativity for inclusion in Jewish, Muslim and Christian faith schools, International Journal of Children's Spirituality, 23:1, 3-16, DOI: 10.1080/1364436X.2017.1410697

To link to this article: https://doi.org/10.1080/1364436X.2017.1410697

曲 Published online: 08 Dec 2017.

Submit your article to this journal $\square$

Џ Article views: 484

Q. View related articles $\square$

View Crossmark data 〔 


\title{
Education, queer theology, and spiritual development: disrupting heteronormativity for inclusion in Jewish, Muslim and Christian faith schools
}

\author{
Seán Henry \\ Department of Education, School of Education, Maynooth University, Maynooth, Co. Kildare, Ireland
}

\begin{abstract}
Voices critiquing heteronormativity in faith schools often rely on an understanding of such schools as arbiters for heteronormative religious orthodoxies. Many proponents of Jewish, Muslim and Christian schools offer compelling responses to such claims by providing inclusive perspectives on faith schooling. By applying a queer reading of temporality to a critique of the latter body of work, this paper will argue that these perspectives, despite their commitments to inclusion, have affinities with logics of heteronormativity through their appeal to a language of hospitality that reproduces adherence to heteronormative binaries and identity frames as originary and normative. From here, the paper will suggest that queer theology's understanding of the transcendent in relation to immanence offers resources for reframing discussions around heteronormativity and faith schools in ways that speak to the inclusive commitments of those critiqued in this paper, while also eschewing reproductive determinism as a basis for understanding spiritual development.
\end{abstract}

\section{ARTICLE HISTORY}

Received 14 October 2017

Accepted 25 November 2017

\section{KEYWORDS}

Heteronormativity; inclusive faith schools; youth identity; spiritual development; queer theology

The last two decades have seen an upsurge in scholarship at the interface between education, schooling, heteronormativity, religiosity and the identities of young people. In particular, emphasis has been on the role faith schools have played in propounding heteronormative logics around identity, as well as on the possibilities of reimagining faith schools in ways that transcend such normative frames. In the case of the former, voices in the Irish context (including O'Higgins-Norman 2009; McNamara and O'Higgins-Norman 2010; Neary 2013, 2017; Fahie 2016, 2017) have problematised the place of the religious within school provision on the grounds that such schools (which are predominantly Catholic in the Republic) have become implicated in regimes of normalcy that have legitimated heterosexual and cisgender identities at the exclusion of queer youth identities. Indeed, critics such as Marples (2005) have argued for the eradication of faith schools altogether, on the 
grounds of their supposed failure to offer an education in line with liberal democratic principles, in which seemingly dissonant identities can co-exist in a spirit of dialogue and cosmopolitanism. Inclusive perspectives concerned with Muslim, Jewish and Christian faith schools across international contexts have offered readings of faith schooling that seek to challenge such associations of faith schools with exclusive principles. Such voices (including Alexander 2000; Waghid and Davids 2014; McDonough 2016) rely heavily on inclusive ideals for the faith school that move away from associations with institutional doctrine (including, we can assume, heteronormative readings of religious and youth identities). In spite of the worthwhile and necessary nature of these writers' contributions, I nonetheless see in the work of these scholars an affinity with heteronormativity through their alignment of inclusion with a language of hospitality. This tendency (which, I hasten to add, is anomalous to the overall spirit of inclusion informing these writers' works) leaves heteronormativity potentially uninterrupted through its recourse to a temporal logic of reproduction that positions queer identity as 'the other to an "us',', to use Aislinn O'Donnell's phrasing $(2015,249)$. Below I set about the task of exploring this affinity, before moving to a discussion of how queer theology's concern for transcendence in relation to immanence offers tools for conceptualising the faith school differently, in ways that are inclusive of people of varying identities, and conducive to an imagining of the spiritual development of a young person's identity as necessarily non-reproductive. But first, an explication of those perspectives on heteronormativity that serve as the overall frame of my argument.

\section{Heteronormativity: origins, temporalities, identities}

I see in the works of Monique Wittig (1992), Michael Warner (1993), Lee Edelman (2004) and Jasbir Puar (2007) critiques of heteronormativity that speak directly to the concerns of this paper.

Describing something as heteronormative involves describing that which grants heterosexuality ontological status within social, cultural, political and economic imaginaries: it involves privileging heterosexuality as having paradigmatic weight in understanding how the world is constituted and how our knowledge of that world can be rendered knowable to begin with. The term was coined by Warner in the 1990s to critique Western political thought's orientation towards seeing the heterosexual couple as representative of 'the principle of social union itself' (1993, xxi), but its roots can be traced (at least theoretically, rather than terminologically) ${ }^{1}$ to 1980 , with the publication of Wittig's 'The Straight Mind'. Wittig offers the concept of 'the straight mind' to describe those totalising discourses within Western culture that perpetuate'the obligatory social relationship between "man" and "woman"' $(1992,27)$. For Wittig, the straight mind is 'clothed' $(1992,27)$ in its tendency for universality, in its alignment of 'what-goes-withoutsaying' heterosexuality $(1992,31)$ with 'general laws which claim to hold true for all societies, all epochs, all individuals' $(1992,27)$. Within such abstractions, 
relationality is reduced to ontological binaries of man/woman, heterosexual/ homosexual, in which the latter of each pairing necessarily becomes a 'different/ other' that exists, at least partly, for the purpose of reflecting the universal quality of the former back upon itself $(1992,29)$. Heteronormativity, understood in this way, becomes what Edelman terms an 'ideological Mobius strip' (2004, 2), a self-reflecting mirror that reproduces, through the 'different/other', the originary Man whose relations with others are at times inflected with a self-referentiality courting the masturbatory.

I refer to this self-referentiality as masturbatory because the binaristic pairings that constitute heteronormative logics exist as a way for allowing the former of each pairing to reproduce the totalising sphere of its own influence through the latter. The creation of Eve from the rib of Adam in order to counter Adam's solitude in the Garden of Eden is a useful illustration of this point: in the Adam/Eve binary, Eve is created in order to reproduce Adam's self-image. Heteronormativity, conceptualised thus, is lived out through a temporal logic of reproduction that sees human relations in the world as reproducing the source or origin that acts as their ontological ground. In the case of the example given, Eve's relationship with Adam exists for the purpose of preserving Adam's place in the world: in this way, Eve was created to sustain a linear view of history as inevitably eschewing Adam's solitude, thereby fulfilling Adam's survival and future. This temporal linearity can be seen as reproductive in its reliance upon an image of the future that replicates or repeats that which has come before, that which has already been determined: in the Adam/Eve binary, the future is Adam's, the origin from which the significance of his relationship with Eve is expressed.

Such a view of time can be seen as antithetical to a queer reading of temporality in the identitarian essentialism upon which its efforts are based. The project of queering temporality is impelled by what Puar refers to as an'anticipatory temporality ... that seeks to catch a small hold of many futures, to invite futurity even as it refuses to script it' $2007, x i x)$. Here, reproductive determinism collapses in favour of an understanding of temporal experience that is non-linear: the future is not something inevitable or self-assured, but is rather unpredictable, uncontainable and seemingly endless. This 'deviant chronopolitics' (Freeman 2005, 58) refuses to straightjacket time within developmentalist ontological categories, and in doing so resists conceptualising identity within terms of reproductive inevitability and essentialism. So understood, time is relieved from a logic of origin (Adam's position as the originary standard against which human relations are judged collapses) and in doing so allows identities to exist simultaneously without being conferred with an oughtness that closes off what they could or should become into the future. Queering temporality allows for the identities of Adam and Eve to be present side-by-side without one acting as the deterministic basis for the other. In this way, Adam's identity and Eve's identity are liberated from essentialist narratives that pigeon-hole identities within convenient (and invasively transparent) boxes. Their futures, in short, become their own, and in this way are queered. 
A queer reading of temporality is significant in a paper (such as this) that is concerned with conceptualising inclusive faith schooling and the place therein of identity and its spiritual development. For Arendt (1977), education takes place at the interface between conservatism and natality: education's work engages with the traditions and histories of the world that we share, in ways that both conserve these traditions, while simultaneously allowing these traditions to be considered anew by virtue of the youthfulness of the young. So conceived, education becomes an encounter with the'radically new' (Biesta 2015, 240), an encounter that does not fetishise newness, but rather takes seriously the traditions that have come before (without being bound prescriptively by these [protecting the new against the old, the old against the new]). From an Arendtian perspective, education continuously oscillates between the old and the new, the what-was and the what-could-be, for one cannot ever exist without the other. I see a queer reading of temporality as being similarly located at such crossroads: to refuse to situate identity along deterministic temporal trajectories is to conserve the embodied and unrepeatable thereness of those who lie beyond my appropriation, while also allowing (by virtue of this conservation) for the newness of their futures to come to realisation in unpredictable and seemingly impossible ways. Insofar as the school exists as a space for offering an inclusive education, a queer reading of temporality has much significance. Inclusion, justified educationally (in the Arendtian sense), demands for a participatory form of associated living with others that conserves the otherness of the other in their otherness, without invasively encroaching upon that otherness in a manner that denudes the new, untold and unforeseen futures of those who identify differently to me. In offering an inclusive education, a school comes to embody a communal way of life that conserves the flesh-and-blood particularity of varying identities through the offering of communal experiences that expose students to encounters with the'radically new' (Biesta 2015, 240), with that which strange and unfamiliar.

The works of Alexander (2000), Waghid and Davids (2014), and McDonough (2016), offer visions of the faith school that directly speak to such ideals. In what follows, I will argue that the authors' perspectives are invaluable for conceptualising the inclusive faith school in ways that are respectively transcendent, attentive to the other and responsive to the diverse particularities of embodied, inclusive school life. From here, I will claim that (in spite of their obvious intentions to the contrary) each authors' work is somewhat hampered by a language of hospitality that has much resonance with heteronormative logics. I will conclude by turning to queer theology as a resource for synthesising each writer's strengths, and applying these to the question of how the spiritual development of young people ought to be understood in the inclusive faith school. 


\section{Hospitality as a condition for conceptualising the inclusive faith school}

The word 'hospitality' has its roots in the Latin hospes, meaning host. Built into its etymology is the idea of the stranger or guest that is welcomed into the guest-chamber by the host that includes them. Hospitality in the Kantian sense speaks to this idea, particularly in his understanding of the term as 'the right of a stranger not to be treated as an enemy when he arrives in the land of another' (as quoted in Zaveduik 2014, 171). Such arrival is made possible by the generosity of the host, whose charity is inflected by the ever-present threat of revocation if the guest were to be judged by the host as no longer requiring it. Hospitality, so understood, becomes a 'welcoming inside' that 'others' the guest in its reliance 'upon images of a pre-existing home, hearth or territory into which someone is invited (or not)' (O'Donnell 2015, 249). ${ }^{2}$ Such a logic rests on a host/guest binary, in which the guest becomes a 'different/other' that exists partly for the purposes of reflecting the magnanimity of the host back upon themselves. The form of relation that constitutes the ontological basis of heteronormativity would seem to reverberate here.

Many perspectives on Jewish schooling are impelled by impulses that are resistant to such appropriative heteronormative logics in their sensitivity to the importance of transcendence in education. Alexander's (2000) 'Education in the Jewish State' stands out as one particularly compelling treatment of Jewish education in the context of Israeli schooling. Averse to 'the exclusion of non-Jewish identities from much thinking about Israeli education', Alexander attempts to offer an ethical vision for education in Jewish faith schools that is'sufficiently broad to encompass competing conceptions of Jewish life espoused by the majority as well as non-Jewish ethical visions affirmed by various minorities' $(2000,491)$. The following by Alexander is illustrative of these inclusive motivations, particularly in his reluctance to grant priority to the 'parochial politics' of Jewish orthodoxy:

For to see the possibility of that which lies beyond, I must be willing to question that which lies at hand ... I therefore speak of transcendence as a higher - rather than an absolute or ultimate - good. However we conceive it, there could always be a better way. This encourages us to recall that every point of view is limited and every framework fallible. $(2000,504)$

Alexander frames Jewish education in these transcendent terms in order to orient education in the Jewish state (including education in Jewish faith schools in this state) towards an ethical ideal that 'transcends the consciousness and history of this particular community' $(2000,504)$. The Jewish faith school broadly commits itself to transcendence, to an encounter with that which is beyond its immediate grasp or control: the new. Such a gesture is educational in its taking seriously the educational imperative of encountering others with whom we relate, in all their bodily specificity and unknowability. In this way, those whose identities deviate from orthodox Jewish doctrine (including, for instance, those that identify as queer) come to be seen as themselves constitutive of, and contributive to, the life of the 
school, and not as anomalous challenges or deviations from the norm that are to be negotiated with or overcome. The queer refusal to situate time along deterministic identitarian lines holds true here: Jewish faith schooling, invested as it is in the educational imperative of encountering that which is radically new, becomes inclusive in the transcendent prerogatives around which Alexander invests his work.

And yet, in spite of these compelling principles for reimagining the Jewish faith school, Alexander's argument seems to jar somewhat in his later characterisation of such an education as grounded 'not only' in 'respect and tolerance of Jews for other Jews, but of Jews of Arabs and other minorities as well' $(2000,505)$. This is typified for Alexander in the imperatives implied by Leviticus $(19: 18,34)$, which 'teaches that the sojourn in Egypt should remind Jews to love strangers, not only kinfolk, as they love themselves' $(2000,505)$. The resonances between this and the language of hospitality come to the fore in the assumptions around the faith school that the author articulates: in this case, the Jewish faith school would appear to be grounded in an originary image of a disembodied Jewish norm that subsequently accommodates those who identify differently (whether Jewish or otherwise). As it appears to me, the binaristic model of relationship resonant with ontological readings of heterosexuality find a home here - Jews are the tolerant hosts within the school, welcoming the non- (or unconventionally) Jewish stranger/guest across the threshold. While Alexander's commitment to transcendence frames his analysis in ways that compellingly traverse the parochial politics of which he is critical, I nonetheless draw attention to the affinities between heteronormativity and the language of hospitality informing his work as a way of bringing to fruition the full import and value of his insights on the inclusive Jewish faith school.

In an attempt to move beyond the association of the Muslim faith school as inevitably exclusive to youth identities at variance to conventional Islam, Waghid and Davids offer a view of the 'imaginative madrassah' that espouses a multicultural vision for education grounded in an attentiveness ( $k h a b r)$ 'towards the other - an attentiveness that can counteract the looming dangers of dogmatism, denial of the other, and injustices' (2014, 125). Waghid and Davids' work, like that of Alexander, is important in its vision for the Muslim faith school as aiming to offer an inclusive cosmopolitan education that cultivates 'human coexistence' for the purposes of problematising those perspectives that exclude, marginalise, silence or assimilate varying populations across and within their differences (including those that might otherwise be coerced into reticence on the grounds of 'their sexual orientations and disabilities') (Waghid and Davids 2014, 126). Such a view resonates with Biesta's reading of education as an encounter with the radically new in its prioritisation of attentiveness to the other, to that which resists constricting deference to narrowly defined institutional norms. In this way, Waghid and Davids' work can be seen as sensitive to the Arendtian commitment to conservatism and natality simultaneously: in attending to the other, the Muslim faith school speaks directly to the thereness of others whose identities are different to me, while also refusing to predetermine what that thereness is or ought to be into the future. 
In spite of this important and necessary insight, however, the reading of multiculturalism offered as the foundations for Waghid and Davids' argument bears some resemblance to the language of hospitality that I believe is worth questioning. The following sentence is particularly telling:'The demand for multiculturalism relates to the recognition of people's different identities without being stigmatised, and the accommodation (inclusion) rather than exclusion of people's differences ...' (Waghid and Davids 2014, 126). Framing inclusion within multicultural contexts in terms of'accommodation' is significant, not least in terms of the word's etymological roots in accommodare meaning to fit one thing to another. Here, to be included is to be situated along a binary between that which does the accommodating, and that which is accommodated: the latter is fitted into the former in ways that grant the former originary and normative status. The 'accommodation' that Waghid and Davids speak about seems to resonate with the dyadic relations that constitute Kantian hospitality, in which the host welcomes the guest on the host's terms in ways that leave uninterrupted the binaristic logics of heteronormativity. Waghid and Davids's reimagination of the madrassah seems to fall short of the understanding of the inclusive faith school I am offering in this paper in its similarity to heteronormative logics of a self-referential and almost onanistic kind. Of course, it would be disingenuous to suggest that Waghid and Davids deliberately set out to do this. Indeed, their cosmopolitan understanding of the faith school as attending to the other holds much import and value that I would hasten to preserve. In the spirit of the writers themselves though, I call into question the language of hospitality that runs, seemingly innocuously, throughout their arguments.

The literature around Christian schooling offers important commitments to inclusion that echo those of Alexander and Waghid and Davids. For my purposes here, I focus on the work around Catholic schooling in Canada by Graham McDonough (2016), for it explicitly addresses the relationship between Catholic faith schools and queer identities. The importance of recognising the multiplicity of Catholic identities lies at the heart of McDonough's endorsement of dissent as a necessary model of inclusive Catholic education. For McDonough, cultivating dissent is essential within Catholic education, for to do otherwise is to grant priority to a limited theorisation of Catholic identity that bolsters the hegemony of the institutional Church and its structures (such resistance finds similar expression in Alexander's transcendent investments). McDonough responds to the concern that encouraging a pedagogical model for dissent would corrupt the identity of a Catholic faith school by arguing that this view 'places one view of Catholicism's distinctiveness above the moral concerns of the faith's own members ... in order to emphasise an image of Catholicism's unsullied unity and permanence' (2016, 169). Here, McDonough challenges conceptualisations of Catholic education that dilute the internal tensions that exist within what it means to espouse a Catholic identity. McDonough's insights are significant as they explicitly allow for alternative perspectives and identities to be voiced, taught and lived out within a Catholic context, voices that could include, for instance, those who identify as both Catholic 
and queer. In light of this, McDonough sees Catholic schooling as important for cultivating a Catholic intellectual and ecclesial social identity understood as 'the coordinated intersection of multiple Catholic identities: a meta-identity' (2016, 172). Hence, dissent becomes an essential part of inclusive Catholic education in creating for youth the opportunities to teach each other what it means to identify with the Church in its diversity of possible expressions, expressions unlimited by conformity to 'a narrow set of membership criteria' that somehow renders a person 'dependent of a superior office-holder' $(2016,173)$. The encounter with the radically new is assured in this reading through McDonough's conceptualisation of the Catholic faith school as open to the diverse particularities of those who are other to what the Magisterium deems 'authentically' Catholic.

However, in spite of these refreshing and contextually responsive understandings of the inclusive Catholic school, McDonough's thesis occasionally relies upon the generalised assumption that those that constitute Catholic schools are necessarily invested in the Church in some way, however diverse that Church might be. McDonough is keen to stress that his model of dissent is one that is complementary to an encounter with non-Catholic and non-Christian identities, but it would appear that the place from which McDonough theorises such an encounter is nonetheless a Catholic one. As I read him, it would seem that, for McDonough, the stranger that is hosted in the 'ecclesial space' of the Catholic faith school needs to be a stranger for whom the Catholic Church bears identitarian significance, in all its diversities and paradoxes. The faith school, by virtue of this assumption, seems to exercise hospitality in its inclusion of those who are different. Taking this logic to its fullest extent, the faith school's inclusive impulses appear to project outwards towards the other, who is (by virtue of this outwardly projection) rendered secondary to a primary or originary (Catholic) standard towards which the other is expected or assumed to gravitate through the host's approach. The heteronormative binary set-up between Adam and Eve appears tantalisingly close to this reading. Problematically, such a view rubs against McDonough's insistence upon the fact of the other's constitutive and participatory presence already within the school. To take McDonough's emphasis on the importance of diversity and inclusion in the Catholic faith school to its complete realisation, it seems that a move away from his assumption that all students and staff in a Catholic school are Catholic would be necessary.

In light of all this, how are we to conceptualise the inclusive faith school in ways that conserve the valuable insights around transcendence, attentiveness and embodied diversity offered by each of the above texts, while also allowing for the simultaneity of conservatism and natality that the language of hospitality (and its heteronormative resonances) elides? Furthermore, how are we to understand the faith school's role in the spiritual development of the young person's identity in light of all this? Below, I make the claim that queer theology's understanding of the transcendent in relation to immanence has the capacity for responding to these questions in ways that are both inclusive and non-reproductive. 


\section{Disrupting heteronormativity: queer theology and the inclusive faith school}

Much resonance exists between education and queer theology that makes queer theology an appropriate lens for understanding the inclusive faith school. As an 'indecent' praxis, queer theology is committed to an understanding of the transcendent that sees transcendence as both arising from and surpassing the particularities of lived experience. In this vein, transcendence for the queer theologian is said to reside in the immanent, but is not in itself of the immanent: transcendence is preserved in this reading, even as the bodily specificity of life in community is maintained (Cornwall 2011, 67). Queer theology's priorities are ultimately grounded in a traditional faithfulness to

... theology's over-againstness even in its immanence - which means that, although theology must always take account of real bodies, bodily experiences, sexualities, and so on, it is also interested in investigating how these are in dialogue with what might be figured as God's transcendence of human discourse. (Cornwall 2011, 67)

Indeed, Marcella Althaus-Reid's characterisation of queer theologians as nomads 'searching for God's nipples and soft lips and trying to bite them in oblique ways in order to achieve some oblique transcendence in their lives' is strikingly illustrative of the corporeal demands that come with being 'traditionally faithful' $(2003,49)$. As I have suggested above, the faith school, in its educational orientation, can be seen as being at the crossroads between immanence and transcendence: the faith school is constituted by the embodied community from which it emerges, but is also (in the educational encounter with the other that it offers) at once both within and beyond the 'teeming, sweaty heat' of the embodied lives that make it up (Todd $2014,233)$. In this way, the education offered in a faith school, in order to be truly faithful ought to take in all seriousness the embodied identities of a school that, in their immanence, come to occupy an uncontainable (or transcendent) open-endedness both unimaginable and impossible. This suggests that the identity of a Jewish school (and that of those that make it up) is not threatened by those who embody lives and identities at variance to Jewish orthodoxy: rather, the Jewish school (in its faithful commitments) lives out its transcendent distinctiveness by virtue of the varying identities of people and relationships that determine (and transcend) its embodied constitution (including those that identify as queer).

Of course, one issue that arises is the nature of the transcendent towards which queer theology orients its efforts (and alongside which conceptions of the inclusive faith school could benefit from positioning themselves). Queer theology, being 'about theology', is concerned with an understanding of the transcendent imaged as 'God'. In terms of conceptualising faith schools in inclusive terms, is it really appropriate to have 'God' as a transcendent referent, with all the baggage that brings? The purpose of this paper is to conceptualise inclusion in the faith school, in ways that eschew the dyadic relations that constitute hospitality through recourse to a language that is both immanent and transcendent simultaneously: 
if I frame this endeavour in theological terms, do I not run the risk of offering a conception of the inclusive faith school that is originally theistic in quality, rather than faithful in the broadest sense (i.e., in a sense that sees religiosity as living a life as a journey towards shared transcendence [Lewin 2017, 2])? Indeed, in drawing from resources from the queer theological tradition, do I not jeopardise the very possibility of conceptualising faith schools without reifying the culture of such a school as necessarily (and exclusively) theistic? Does my turn to queer theology not reiterate the hospitable gesture of the (theistic) host? In gleaning possible responses to these questions, a focus upon the intricacies of how queer theology does its work would prove useful at this point.

The strategies queer theology employs in gaining insight on the transcendent are characterised by what I term a 'self-refuting slippery-ness' at once invested in the pursuit of God's transcendent significance while also refusing to situate the figure of 'God' within a normative identitarian stranglehold. The chance of (a)theistic apostasy is always and necessarily there within queer theology, a scholarly endeavour in which disbelief and disaffiliation are embraced as equally likely and appropriate identitarian responses to the search for transcendence in our world (Cornwall 2011 , 208). Queer theology's engagement with God arises from a fundamental, corporeal commitment to transcendence and not necessarily from a self-referential commitment to 'God', Godself (conventionally understood). Indeed, as Jonathan Long notes, transcendence and theism are not necessarily identical terms (2000, 151). For queer theologians across varying monotheistic and Abrahamic traditions, God acts as a figure through which the ineffable becomes tentatively and transiently articulable, if only to highlight the futility of such articulation itself (as well as the almost embarrassing inadequacy of those identity labels so often affixed to such a figure). From a queer Muslim perspective, Andrew K.T. Yip and Amna Khalid draw attention to the fact that queer Muslims' search for Allah may engage with institutionalised Islam, but must do so in a way that is 'inclusive, fluid, and listening ... not constrained by its taken-for granted precepts and practices' $(2010,109)$. In this spirit, the project of queer theology, as Linn Tonstad observes, becomes an 'ideal-theological project', that 'in its very success, loses sight of the God of whom it attempts to speak'. (2016, 140). Althaus-Reid similarly characterises the area's methodological suspicion of conservative theological orthodoxy and dogmatic theism in this way: 'a queer theological praxis ... has the instability of a becoming and not the certainty of an arrival' $(2008,109)$. This instability is further expressed for Althaus-Reid in the two rules that she believes the queer theologian must follow: 'First, never repeat, and second, keep decency at bay (in order to fight the theological vocation of normalising discourses about God)' $(2003,51)$. This aversion to repetition is echoed by queer Jewish theologian Rachel Adler when she writes of how the Jewish tradition 'must allow itself to be challenged by the new categories and experiences [queers] bring. This may require some serious rethinking of things the tradition used to take for granted' $(2016,7)$. The temporally repetitive, self-referential loop of orthodox theology has no place in the queer pursuit for 
transcendence: repeating the orthodoxies of old, the identitarian investments of the host, is of little interest to those committed to queer theological endeavour, an endeavour so heterodox and 'indecent' that it renders even the most fundamental figures of theology (such as God!) up for grabs.

Interestingly, Cornwall compares Althaus-Reid's work to a 'moving kind of Christian atheism which rejects the false deities wrought in hegemonic bluster' $(2011,150)$. This comparison speaks to the heart of queer theology's intrinsic queerness: at once theist and atheist, theological and non-theological, within and without. This is not to suggest that queer theology is without its commitments: indeed, steadfast faith in the transcendent, in that which is 'indubitable but radically unknowable' remains constant (Loughlin 2007, 10). Queer theology's appropriateness in conceptualising what we mean by an inclusive faith school therefore comes not from a commitment to framing the faith school in necessarily theistic terms, but rather from a commitment to a conceptualisation of a faith school that is open to the identitarian possibility of theism (of 'God') (insofar as such a possibility is informed by the embodied community constituting the identities of the school) as well as to the equally weighted possibility of fracturing (or, indeed, discarding) the edges of identitarian certainty where necessary for the sake of true transcendence (a transcendence that, in an inclusively educational way, resists heteronormativity and its unyielding temporalities and identitarian constrictions). The paper's offering of queer theology in reconceptualising the inclusive faith school takes seriously the educational quality to school life realised in an embodied turn towards the transcendent other, in the other's terms: by turning to the self-refuting slippery-ness of queer theology, I deliberately seek to conceptualise the faith school in ways that are broad enough to allow me to be responsive to both the transcendent (and educational) significance of life in faith schools (a significance that necessarily speaks across varying identitarian faith traditions committed to the transcendent), as well as to the potential (non-)place of 'God' (Muslim, Jewish, Christian) within such a life. Education is never without its transcendent possibilities: if God emerges as a priority for someone as part of one's spiritual development in a faith school, so be it, but equally if the opposite happens, so be it. Queer theology, situated at the interstices between what is there and not-there, has the tools to allow varying identitarian possibilities to sit at the table as constitutive parts of the table itself, a constitution disavowed from heteronormative logics of origin expressed in the host-guest binary.

Reflecting on the role of the inclusive faith school in terms of the development of a young person's spiritual identity more explicitly, then, this paper makes the claim that one of the many purposes of the faith school is to provide an educational space in which the spiritual and/or religious identities of those taught there are developed and conserved in all seriousness, but in a way that is inflected with the Arendtian demand for natality that education calls for. Such seriousness would resist deterministic, linear or reproductive approaches to spiritual development, for such approaches elide the irreducibility of the other, whose identity (as argued 
above) escapes neat categorisation or temporal alignment. Queer theology, as I read it, offers the inclusive faith school resources for seeing the spiritual development of the young person as intrinsically slippery and self-refuting: the development of a young person's identity in ways that simultaneously speak to and transcend their embodied thereness ought to be one that is uncontainable in its constitution, and unpredictable in its becoming (for to see spiritual development otherwise is to neglect the fluidity and potentiality of identity that makes the educational and spiritual development of a person possible to begin with). Read in this way, the experience of spiritual development of, say, a Catholic student in an inclusive Catholic faith school would be one where the preservation of Catholic affiliation is not necessarily a priority: the priority would be a queer appreciation for transcendence, not repetition. ${ }^{3}$ Utilising queer theology as a lens for imagining inclusive faith schools is not, therefore, a matter of orthodox theological or (a)theistic identitarian commitment, but is more an educational commitment to transcendence in relation to immanence, a commitment that embraces the spiritual identity of the young person in the educational encounter that it offers, while also refusing to script what that identity ought to be as a consequence of this encounter: in this way, queer theology's commitment to the transcendent is one that renders any concomitant identity development in education as fluid enough to 'invite futurity even as it refuses to script it', thereby stepping out of attempts to cosset identity within matrices of a predictable and repetitive kind (for identity, in its embodiment, is so polyvalent and fluid that it becomes impossible to position along a predetermined path). The faith school comes to be seen within this analysis as an inclusive space liberated from logics of origin, in which the spiritual development of its students has the potential to subvert (in queer fashion) the temporal generalisation that to develop spiritually is to inevitably commit to an institutional or identitarian orthodoxy. I argue that it is in these simultaneously horizontal and vertical terms (terms that the lived experiences of queer theological praxis exemplify [Yip and Khalid 2010, 109]) that we can think about the inclusive faith school (whether Jewish, Muslim or Christian) in a manner that allows for the spiritual development of young people to be conserved in non-reproductive ways, in ways that disrupt heteronormativity while also always embodying the inclusive spirit of those writers I have engaged with in this paper.

\section{Notes}

1. I say theoretically rather than terminologically, as other voices were also offering views of what heteronormativity is, albeit without recourse to the term itself. A seminal text at this time was Rich's (1996) 'Compulsory Heterosexuality and Lesbian Existence', which (in resonant ways to Wittig) saw heterosexuality as a compulsory frame within Western experience.

2. Interestingly, Langmann (2011) problematises the concept of hospitality (so understood) in relation to education, calling for a reconceptualisation of the term away from the dyadic relations that serve as the basis of my critique. She writes of 
how education for hospitality ought to involve 'a refusal to conceive the host and the guest as pre-constituted identities, and the recognition that every encounter involves both fixation and the impossibility of fixation' (Langmann 2011, 407). This is a reading of hospitality that I am comfortable with, not least for its queer resonances, as well as for its affinities to the simultaneity of immanence and transcendence that I see as characteristic of the educational encounter itself. Her insights speak directly to the concerns of this paper in this regard, but have been omitted to offer more space on how queer theology has the resources to respond to this question.

3. It is important to note that such a priority would not necessarily exclude the deepening of a student's religious affiliation either: what queer theology offers my reading of spiritual development in the inclusive faith school is a way of looking at the transcendent that avoids understanding spiritual development as inevitably demanding identitarian commitment one way or the other.

\section{Disclosure statement}

No potential conflict of interest was reported by the author.

\section{Funding}

This work was supported by Irish Research Council [grant number GOIPG/2016/472].

\section{Notes on contributor}

Seán Henry is a third-year PhD student at the Department of Education, Maynooth University, Ireland. His thesis is entitled 'Towards a Queer Religious Ethos: Disrupting Heteronormativity in Faith Schools'. His research interests are in the philosophy of education, religious education, faith schooling, queer and feminist theory, religious studies and queer and contextual theologies.

\section{References}

Adler, Rachel. 2016. "Queer Jews Talking Their Way In." European Judaism 49 (2): 6-13.

Alexander, Hanan. 2000. "Education in the Jewish State." Studies in Philosophy and Education 19: 491-507.

Althaus-Reid, Marcella. 2003. The Queer God. London: Routledge.

Althaus-Reid, Marcella. 2008. "The Bi/Girl Writings: From Feminist Theology to Queer Theologies." In Post-Christian Feminisms: A Critical Approach, edited by Lisa Isherwood, 105-116. Aldershot: Ashgate.

Arendt, Hannah. 1977. "The Crisis in Education." In Between Past and Future: Eight Exercises in Political Thought, edited by Hannah Arendt, 173-196. New York: Penguin.

Biesta, Gert. 2015. "Freeing Teaching from Learning: Opening up Existential Possibilities in Educational Relationships." Studies in Philosophy and Education 34: 229-243.

Cornwall, Susannah. 2011. Controversies in Queer Theology. London: SCM Press.

Edelman, Lee. 2004. No Future: Queer Theory and the Death Drive. Durham: Duke University Press. Fahie, Declan. 2016. "Spectacularly Exposed and Vulnerable - How Irish Equality Legislation Subverted the Personal and Professional Security of Lesbian, Gay and Bisexual Teachers." Sexualities 19 (4): 393-411. 
Fahie, Declan. 2017. “Faith of Our Fathers - Lesbian, Gay and Bisexual Teachers' Attitudes towards the Teaching of Religion in Irish Denominational Primary Schools." Irish Educational Studies $1-16$.

Freeman, Elizabeth. 2005. “Time Binds, or, Erotohistoriography." Social Text 23 (3-4; 84-85): 57-68. Langmann, Elisabet. 2011. "Representational and Territorial Economies in Global Citizenship Education: Welcoming the Other at the Limit of Cosmopolitan Hospitality." Globalisation, Societies and Education 9 (3-4): 399-409.

Lewin, David. 2017. Educational Philosophy for a Post-secular Age. Abingdon: Routledge.

Long, Jonathan. 2000. "Spirituality and the Idea of Transcendence." International Journal of Children's Spirituality 5 (2): 147-161.

Loughlin, Gerard. 2007."Introduction: The End of Sex." In Queer Theology: Rethinking the Western Body, edited by Gerard Loughlin, 1-34. Oxford: Blackwell.

Marples, Roger. 2005. "Against Faith Schools: A Philosophical Argument for Children's Rights." International Journal of Children's Spirituality 10 (2): 133-147.

McDonough, Graham. 2016. "Cultivating Identities: The Catholic School as Diverse Ecclesial Space." Philosophical Inquiry in Education 23 (2): 160-177.

McNamara, Gerry, and James O'Higgins-Norman. 2010. “Conflicts of Ethos: Issues of Equity and Diversity in Faith-based Schools." Educational Management, Administration and Leadership 38 (5): 534-546.

Neary, Aoife. 2013. "Lesbian and Gay Teachers' Experiences of 'Coming Out' in Irish Schools." British Journal of Sociology of Education 34 (4): 583-602.

Neary, Aoife. 2017. LGBT-Q Teachers, Civil Partnership and Same-Sex Marriage: The Ambivalences of Legitimacy. New York: Routledge.

O'Donnell, Aislinn. 2015. "Beyond Hospitality: Re-imagining Inclusion in Education." In The Inclusion Delusion? Reflections on Democracy, Ethos and Education, edited by Aislinn O'Donnell, 249-269. Bern: Peter Lang AG.

O'Higgins-Norman, James. 2009. "Straight Talking: Explorations on Homosexuality and Homophobia in Secondary Schools in Ireland." Sex Education 9 (4): 381-393.

Puar, Jasbir K. 2007. Terrorist Assemblages: Homonationalism in Queer times. Durham: Duke University Press.

Rich, Adrienne. 1996. "Compulsory Heterosexuality and Lesbian Existence." In Feminism and Sexuality: A Reader, edited by Stevi Jackson and Sue Scott, 130-141. New York: Columbia University Press.

Todd, Sharon. 2014. "Between Body and Spirit: The Liminality of Pedagogical Relationships." Journal of Philosophy of Education 48 (2): 231-245.

Tonstad, Linn Marie. 2016. God and Difference: The Trinity, Sexuality, and the Transformation of Finitude. New York: Routledge.

Waghid, Yusef, and Naraan Davids. 2014. "Muslim Education and Its (In)commensurability with Multiculturalism: Some Thoughts on the Imaginative Madrassah." Policy Futures in Education 12 (1): 124-130.

Warner, Michael. 1993. Fear of a Queer Planet. Queer Politics and Social Theory. Minneapolis: University of Minneapolis Press.

Wittig, Monique. 1992. The Straight Mind and Other Essays. Boston, MA: Beacon Press.

Yip, Andrew K. T., and Amna Khalid. 2010. “Looking for Allah: Spiritual Quests of Queer Muslims." In Queer Spiritual Spaces: Sexuality and Sacred Places, edited by Kath Browne, Sally Munt and Andrew K. T. Yip, 81-109. Farnham: Ashgate.

Zaveduik, Nicholas. 2014. "Kantian Hospitality." Peace Review: A Journal of Social Justice 26 (2): 170-177. 